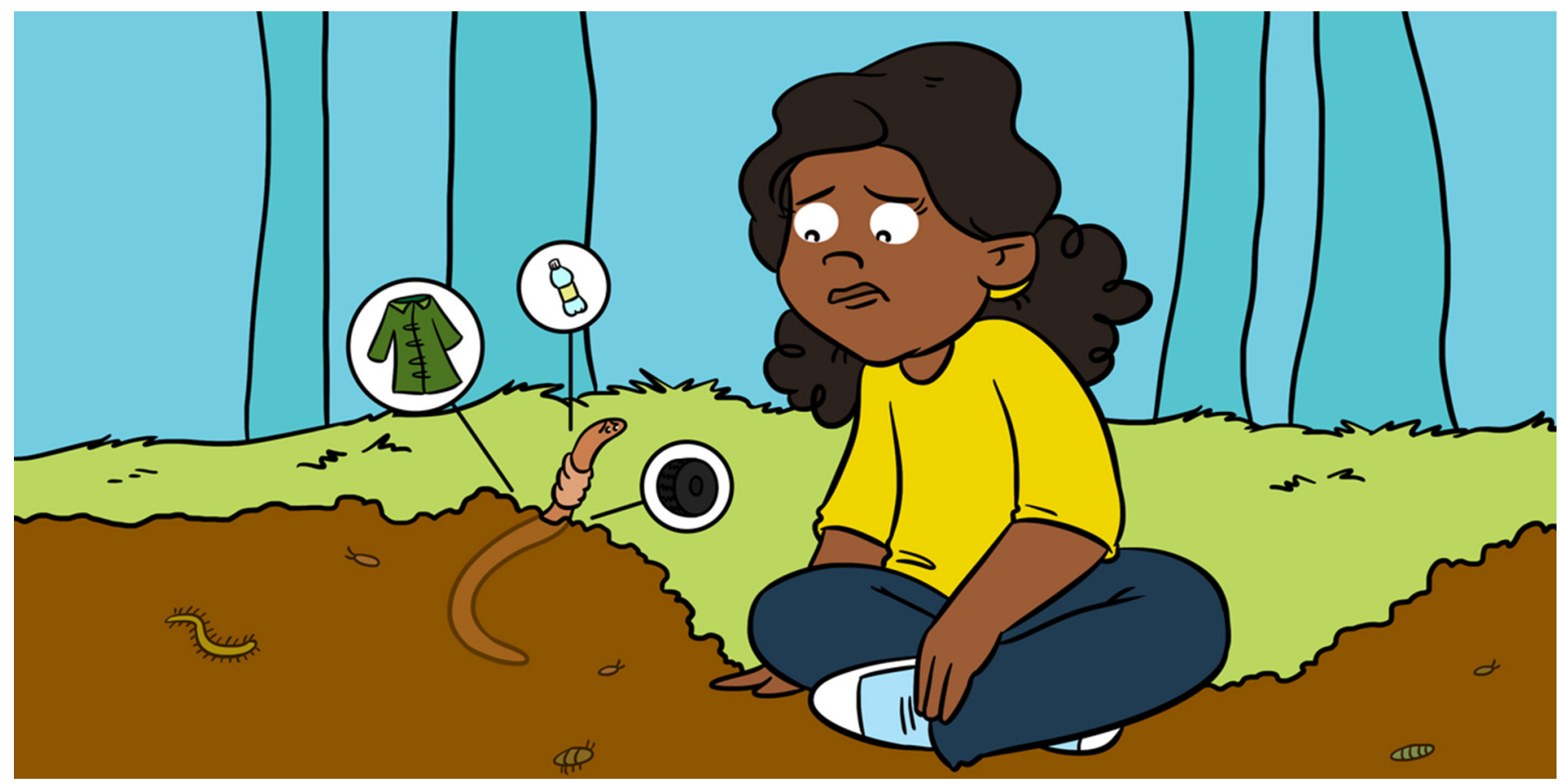

\title{
HOW SOIL INVERTEBRATES DEAL WITH MICROPLASTIC CONTAMINATION
}

\section{Carlos Barreto ${ }^{1 * t}$, Matthias C. Rillig ${ }^{2,3 t}$, Walter R. Waldman ${ }^{4 t}$ and Stefanie Maaß ${ }^{3,5 t}$}

${ }^{1}$ Department of Biology, Biotron Experimental Climate Change Research Centre, Western University, London, ON, Canada

${ }^{2}$ Plant Ecology, Institute of Biology, Freie Universität Berlin, Berlin, Germany

${ }^{3}$ Berlin-Brandenburg Institute of Advanced Biodiversity Research (BBIB), Berlin, Germany

${ }^{4}$ Center of Science and Technology for Sustainability, Federal University of São Carlos, Sorocaba, Brazil

${ }^{5}$ Plant Ecology and Nature Conservation, Institute of Biochemistry and Biology, Universität Potsdam, Potsdam, Germany

YOUNG REVIEWERS:

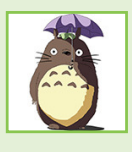

ASTÈRE

AGE: 8

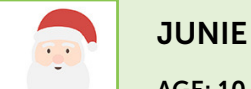

Small animals living in soils, called soil invertebrates, represent a very diverse group of soil inhabitants. They include earthworms, woodlice, spiders, springtails, mites, and some insects. Soil invertebrates feed on dead plants, on fungi and bacteria, or on other soil invertebrates. The many ways soil invertebrates interact with each other, and the large number of different species, make life in soils complex and difficult to understand. Unfortunately, soil invertebrates have been dealing with soil pollution, including contamination with tiny particles of plastic called microplastics for decades now. But are microplastics harmful to these organisms? Can microplastics be passed between soil invertebrates when one feeds on another? Most questions about microplastics and soil invertebrates have been investigated using earthworms, but a few studies on others, like 
SOIL

\section{INVERTEBRATES}

Small, soil-dwelling animals without backbones or bony skeletons.

Figure 1

Examples of soil invertebrates of different size. (A) water bear, (B) wheel animal, (C) nematode, (D) potworm, (E) springtail, (F) mite, (G) spider, (H) beetle, (I) woodlouse, (J) earthworm, (K) centipede, and (L) millipede. Illustrations do not represent the actual size of the soil invertebrates. springtails, mites, and nematodes, also exist. In this article, we summarize the effects of microplastics on soil invertebrates.

\section{WHO ARE THE HIDDEN SUPERHEROES IN THE SOIL AND WHAT ARE THEIR JOBS?}

Many animals live in soils, but... why can we not see them all? The tiny animals living in soils are called soil invertebrates, and they vary greatly in size. Some species are even smaller than the diameter of a human hair! We can classify soil invertebrates into three main groups based on their sizes [1] (Figure 1). Macroinvertebrates are big invertebrates like earthworms, woodlice, spiders, millipedes, centipedes, and some insects like beetles. They are bigger than $2 \mathrm{~mm}$ and can create their own living spaces in soils. Mesoinvertebrates have an intermediate size $(0.1-2 \mathrm{~mm})$ and live in air-filled pore spaces in soils. Examples include springtails [2], mites, and potworms. Microinvertebrates are $<0.1 \mathrm{~mm}$, so small that we cannot see them without the help of a microscope. They live in the water that is present around soil particles. Examples include nematodes, rotifers, and water bears.

Each soil invertebrate group likes different foods [3]. In general, some soil invertebrates, like spiders, feed on other soil invertebrates. Others, like springtails, feed on microbes like fungi and bacteria; and still others, like earthworms, feed on dead plants. These feeding relationships are part of a complex food web that is composed of many species (Figure 2) and many interactions.

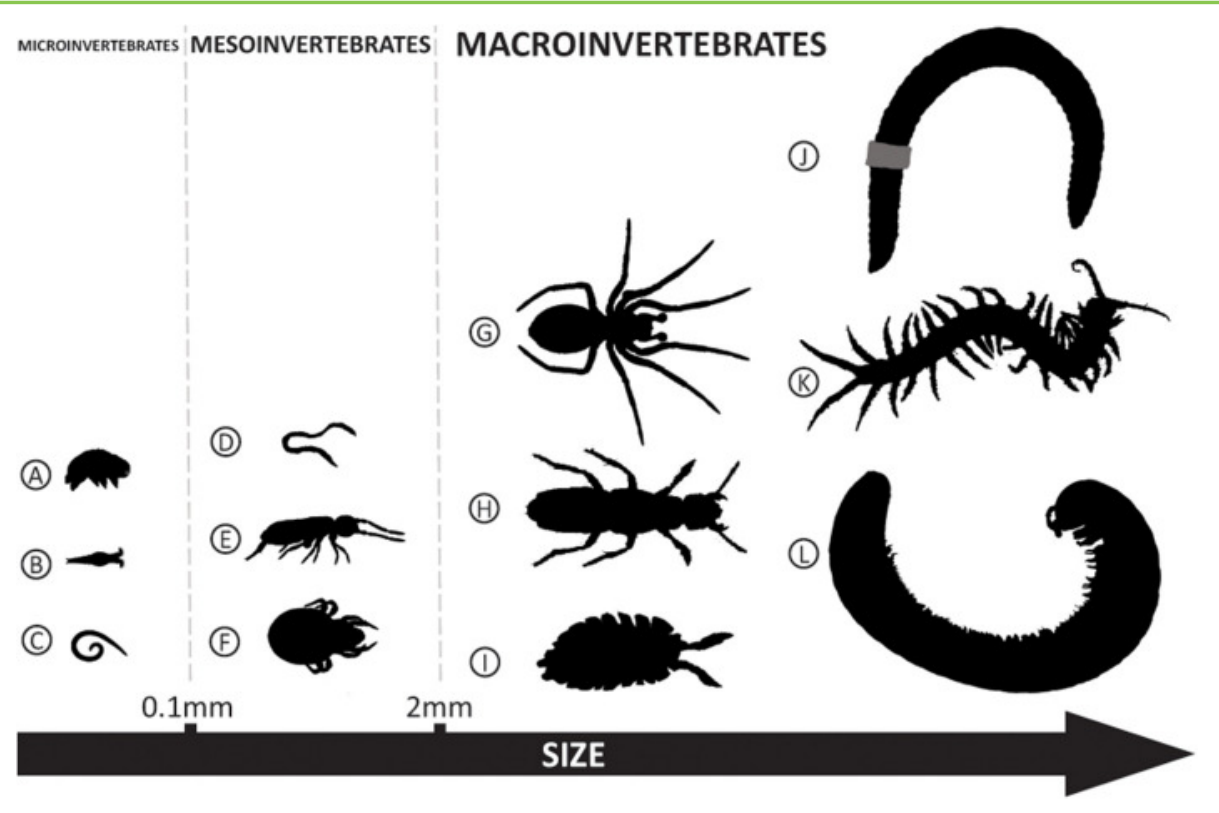

Figure 1 
Figure 2

Examples of soil invertebrates.

Microinvertebrates $(<0.1 \mathrm{~mm})$ include $(\mathbf{A})$ water bears and (B) nematodes; mesoinvertebrates (between 0.1 and $2 \mathrm{~mm}$ ) include (C) potworms, (D-G) springtails, and $(\mathrm{H}, \mathrm{I})$ mites;

macroinvertebrates $(>2 \mathrm{~mm}$ ) include (J) woodlice, (K) beetles, (L) earthworms, (M) millipedes, (N) centipedes, and (O) spiders (photo credits: A,C-O: Frank Ashwood; B: Devdutt Kamath).

\section{MICROPLASTICS}

Small plastic particles $(<5 \mathrm{~mm})$ which can be harmful to soil and aquatic life.
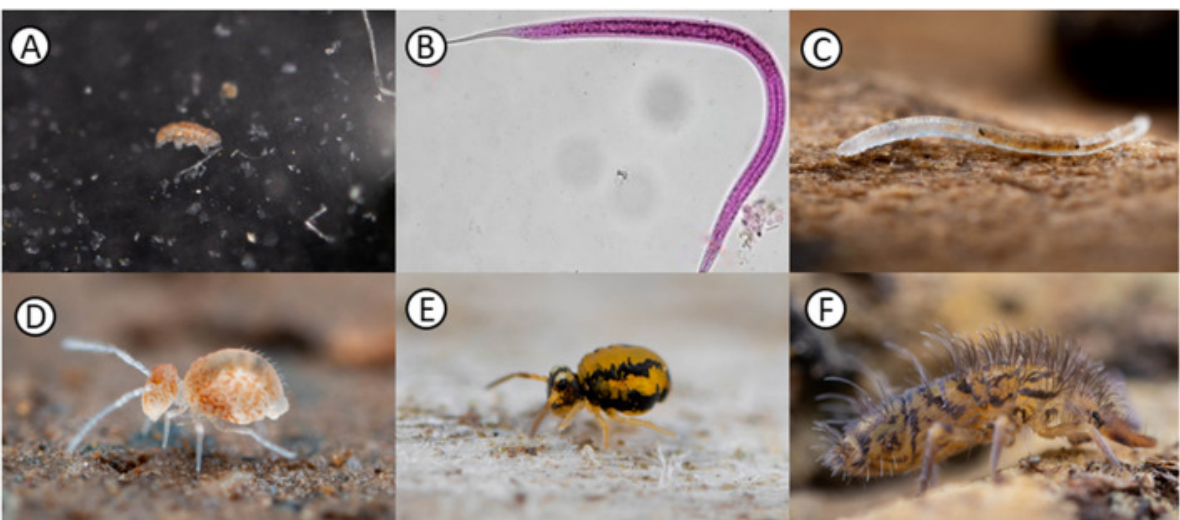

(e)

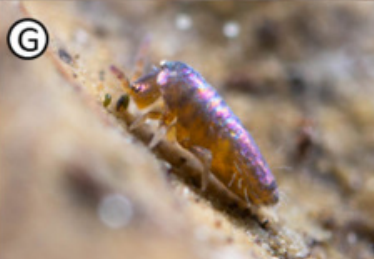

$\Theta$
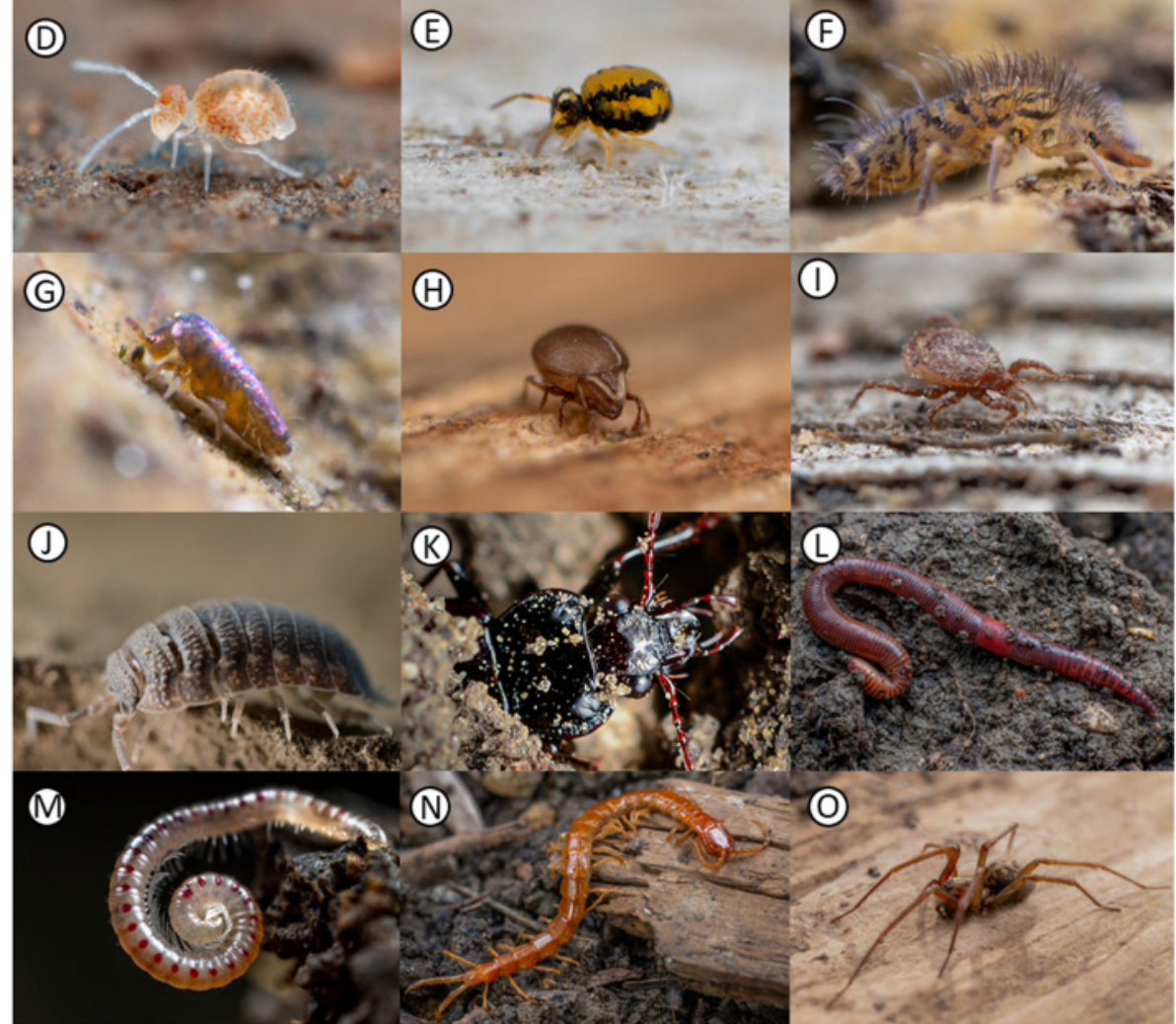

Figure 2

All soil invertebrates are important for the environment. For example, water bears can colonize new environments and serve as food for other organisms. Nematodes can help cycle nutrients through the soil, with the help of springtails, mites, woodlice, and earthworms. Woodlice, springtails, and some mites [4] help decompose leaves and other formerly living materials in the soil [5], and they also help trap carbon from the atmosphere in the soil. Earthworms help rainwater to infiltrate into the soil. Some soil invertebrates may feed on organisms that cause plant diseases, protecting plants from these pests. Each in their own way, these creatures help to keep the soil healthy, which is also necessary to ensure the quality of our food.

\section{THE THREAT OF MICROPLASTICS}

Unfortunately, the homes of many soil invertebrates have been invaded by pollutants such as microplastics. Microplastics are small particles $(<5 \mathrm{~mm})$ that are created in many ways (Figure 3; Box 1). For example, when cars are driven on roads, their tires wear out and 
Figure 3

Examples of microplastics. (A) Springtail and urea-formaldehyde particles. (B) Springtail and plastic scraped off a pop bottle. (C) Polypropylene microbeads. (D) Polypropylene microfibers. (E,F) Adult nematodes with fragments of polystyrene. (G) Particles formed by tire abrasion. (H) Close-up of a polyurethane sponge. (I) Powder-like polypropylene (photo credits: A,B: C. Reinhart and D. Daphi, C,I: Stefanie Maaß, D: Carlos Barreto, E,F: Shin Woong Kim, G Eva Leifheit, $\mathrm{H}$ : Walter Waldman).

\section{ADDITIVES}

Chemicals that make the plastic more colorful flexible, or less flammable.

\section{DEGRADATION}

The breakdown or separation of something into simpler/smaller parts.

\section{LEACHING}

When a liquid substance is released away from its solid source.
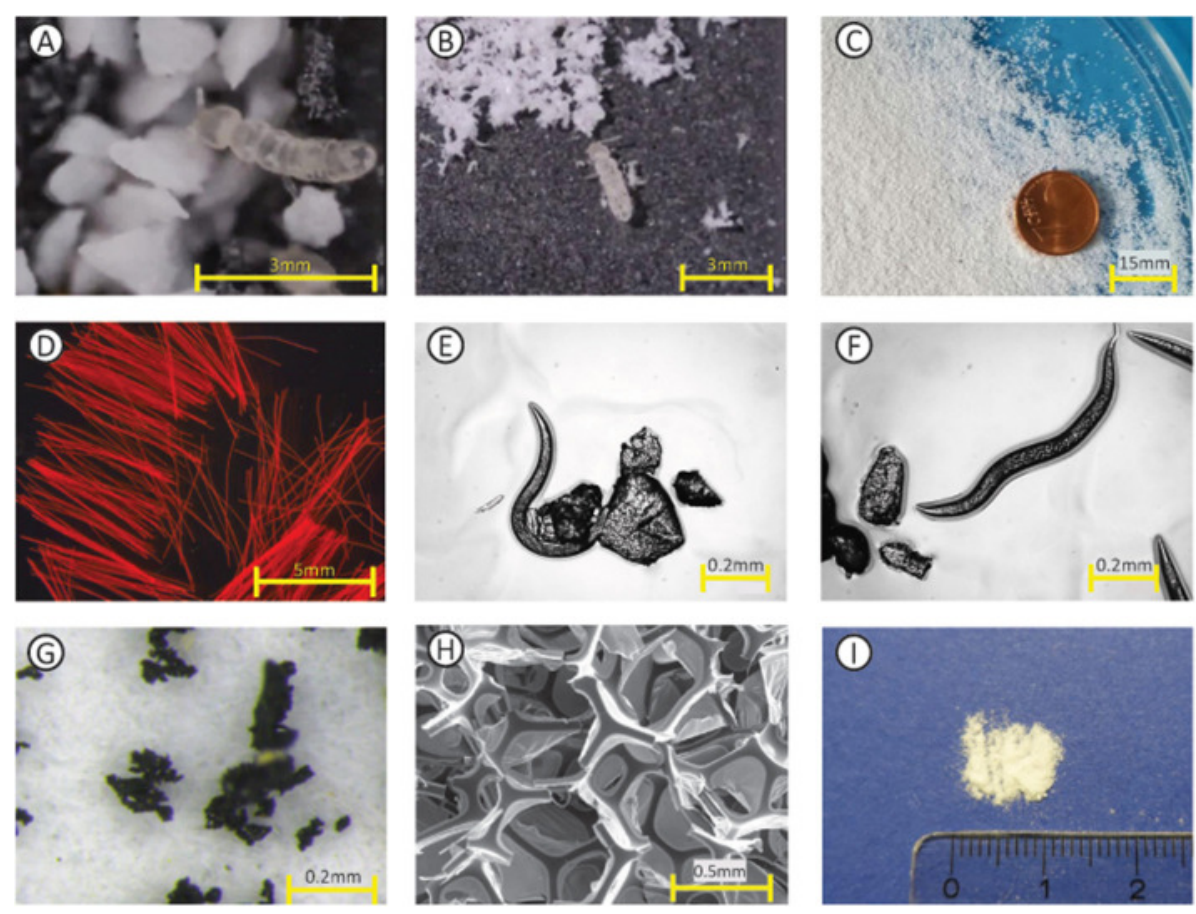

Figure 3

lose microplastics, which can be picked up by the wind and end up in soils. Also, when we do laundry, plastic fibers are released from the clothes into the water. One fleece coat alone can release up to one million fibers per wash cycle! Many of these plastic fibers end up in the sewage, which is a problem because treated sewage can be used to fertilize the soil that crops are grown in. Microplastics can also enter the soil through plastic trash and rainwater.

Microplastics have a huge range of chemical and physical properties. Plastic materials often contain additives. These additives can make microplastics even more harmful to the environment, especially once the microplastic particles start to undergo degradation. Plastic particles become increasingly brittle due to sunlight, water, and the surrounding soil particles that rub on them. Over time, microplastic particles fall apart into even smaller particles, called nanoplastics. During degradation, the additives slowly start to leach out of the microplastics, into the soil. The particles can also leach into the tissues of organisms if they are eaten. Unfortunately, we still do not know much about the effects that leaching of additives from plastics can have on the environment.

So, microplastic particles can clearly affect the soil, but how do they affect soil invertebrates? [6] If we look at earthworms, with their constant appetite for dead leaves and their intense digging activities, we can easily imagine that they regularly ingest microplastic particles and transport them deep into the soil. Not only by feeding, but also on their skin, they can transport these particles. The same has 
Box 1 | Sources of microplastics in soils.

\begin{tabular}{|c|c|c|}
\hline Object & $\begin{array}{l}\text { Plastic } \\
\text { (formal } \\
\text { names) }\end{array}$ & Comment \\
\hline Paints & $\begin{array}{l}\text { Epoxy } \\
\text { and alkyd } \\
\text { resins }\end{array}$ & $\begin{array}{l}\text { Microplastics are formed from sanding } \\
\text { painted surfaces and when paint peels } \\
\text { off walls or other structures. }\end{array}$ \\
\hline $\begin{array}{l}\text { Plastic } \\
\text { bags }\end{array}$ & $\begin{array}{l}\text { Low-density } \\
\text { polyethylene } \\
\text { (LDPE) }\end{array}$ & $\begin{array}{l}\text { When plastic bags are discarded } \\
\text { improperly, they might end up on the } \\
\text { ground and get degraded by the sun, } \\
\text { eventually forming microplastics. }\end{array}$ \\
\hline $\begin{array}{l}\text { Mulching } \\
\text { films }\end{array}$ & $\begin{array}{l}\text { Low-density } \\
\text { polyethylene } \\
\text { (LDPE) }\end{array}$ & $\begin{array}{l}\text { Some farmers use plastic mulching films } \\
\text { to protect plants from water loss. These } \\
\text { plastics will break down from sun } \\
\text { exposure and form microplastics. }\end{array}$ \\
\hline Tires & $\begin{array}{l}\text { Polyisoprene } \\
\text { (natural } \\
\text { rubber) }\end{array}$ & $\begin{array}{l}\text { Although tires are made primarily of } \\
\text { natural rubber, they also contain additives } \\
\text { and their toxicity is currently being tested. }\end{array}$ \\
\hline Foam & $\begin{array}{l}\text { Polystyrene } \\
\text { (PS) }\end{array}$ & $\begin{array}{l}\text { Foams are widely used in house insulation } \\
\text { and in packaging to protect products } \\
\text { during transport and storage. Damage and } \\
\text { breakdown of foams produce } \\
\text { microplastics. }\end{array}$ \\
\hline Glitter & $\begin{array}{l}\text { Polyethylene } \\
\text { terephthalate } \\
\text { (PET) }\end{array}$ & $\begin{array}{l}\text { Glitter spreads easily and can detach from } \\
\text { makeup and toys and contaminate soil. }\end{array}$ \\
\hline $\begin{array}{l}\text { Water } \\
\text { bottles }\end{array}$ & $\begin{array}{l}\text { Polypropylene } \\
\text { (PP) }\end{array}$ & Breakdown of improperly disposed water \\
\hline $\begin{array}{l}\text { Soft } \\
\text { drink } \\
\text { bottles }\end{array}$ & $\begin{array}{l}\text { Polyethylene } \\
\text { terephthalate } \\
\text { (PET) }\end{array}$ & $\begin{array}{l}\text { and soft drink bottles can contaminate } \\
\text { the soil. }\end{array}$ \\
\hline Clothes & $\begin{array}{l}\text { Polyesters } \\
\text { and } \\
\text { polyamides }\end{array}$ & $\begin{array}{l}\text { Synthetic fibers release microfibers during } \\
\text { washing, and they end up in the soil via } \\
\text { fertilizers prepared from sewage. }\end{array}$ \\
\hline
\end{tabular}

been shown for springtails. What does this mean? On the one hand, the microplastic particles will become more degraded as they pass through the guts of soil organisms. But on the other hand, once particles are carried deeper into the soil, degradation slows down due to the absence of sunlight and reduced microbial activity. In other words, the deeper the particles move into the soil, the longer it takes for them to totally degrade.

\section{MICROPLASTICS CAN AFFECT THE HEALTH OF SOIL ORGANISMS}

Soil organisms feel sick when they eat microplastics, and this is has been reported for earthworms and springtails. After feeding on microplastic particles, earthworms suffered from several health problems, including inflammation and damage to the gut [7]. Additionally, ingestion of microplastics put the immune system of the earthworms on higher alert than usual. Springtails that ingested microplastics suffered changes in the helpful bacteria living in 
their digestive systems [8]. Both earthworms and springtails grew more slowly, had fewer offspring, and died more often after they ingested microplastics.

This sounds like bad news for nematodes, but here is the good news: scientists have not seen a build-up of microplastic particles in organisms over time, which means that they might not suffer that much harm after all. However, it is likely that microplastic particles can be passed on along through the soil food web, from microbes like fungi, to springtails, to predatory mites; or from microbes to earthworms, and then to chickens [9] - and maybe also to humans! We still do not know much about how microplastics move through the soil food web, but research is progressing quickly on that topic. Despite these concerns, scientists have found a gleam of light! One research group reported that certain bacteria in the guts of earthworms can digest ingested microplastics, leading to high degradation rates [10]. This means that bacteria might be able to speed up the destruction of microplastics in soil. Can other soil invertebrates do the same? We simply do not know yet.

\section{WHAT CAN WE DO TO PROTECT SOIL INVERTEBRATES?}

You might wonder why scientists have not made more progress answering important questions about the effects of microplastics on soils and the organisms that live there. Unfortunately, these studies face numerous difficulties. For example, we do not yet have a reliable method for measuring the amount of all types of microplastics in all types of soil. Also, many studies consist of short-term experiments that are done in the lab, instead of long-term studies done outdoors in the soil. The huge diversity of plastic types and additives makes it impossible to test everything under real-world conditions. Lab experiments are only informative to a certain degree. Lab experiments are also difficult because not all soil organisms will survive in the laboratory environment. But rest assured: scientists are doing their best to solve these problems. In the meantime, there are ways that you can help!

We should all try our best to minimize the future addition of plastics of any type and size into the environment. You may already know some of the most important ways! Avoid single-use plastic items like plastic cups or straws. Choose your favorite metal or reusable plastic cup, and a metal straw, and keep them handy in your lunch bag! It is also important to put plastic waste in the correct recycling container: This can help reduce the amount of plastic that ends up in the water and soil. Additionally, avoid beauty products that have microplastics in their ingredients, like some conditioners! There are alternative products that are free of microplastics, and some smartphone apps can help you choose the best ones for you. To reduce the number of plastic fibers released into the environment, try not to throw away old clothes 
just because you do not want them anymore! Instead, try to sell, donate, or reuse them in a creative way. Let's join forces and save our tiny soil superheroes from further microplastic pollution. It is worth every effort!

\section{ACKNOWLEDGMENTS}

We thank Frank Ashwood (Forestry Commission UK), Shin Woong Kim (Freie Universität Berlin), and Devdutt Kamath (University of Guelph) for kindly allowing us to use their soil invertebrate pictures. We thank C. Reinhart, D. Daphi, and Eva Leifheit (Freie Universität Berlin) for the pictures of plastics. We thank Anderson Abel de Souza Machado, Alice A. Horton, and Taylor Davis for their work on the book chapter on microplastics which was the starting point for this article. MR acknowledges funding from an ERC Advanced Grant (694368). This work was also partly funded by the German Federal Ministry of Education and Research BMBF within the Collaborative Project Bridging in Biodiversity Science-BIBS (phase 2, funding number 01LC1501B). We thank Helen Phillips, Rémy Beugnon, and Malte Jochum, the editors of the Soil Biodiversity collection, for such a great and important initiative. Last, but not least, we thank our young reviewers for their comments.

\section{REFERENCES}

1. Coleman, D. C., Callaham, M. A., and Crossley, D. A. Jr. 2018. Fundamentals of Soil Ecology, 3rd Edn. London: Academic Press. p. 376.

2. Potapov, A. 2020. Springtails - worldwide jumpers. Front. Young Minds 8:545370. doi: 10.3389/frym.2020.545370

3. Erktan, A., Pollierer, M., and Scheu, S. 2020. Soil ecologists as detectives discovering who eats whom or what in the soil. Front. Young Minds 8:544803. doi: 10.3389/frym.2020.544803

4. Barreto, C., and Lindo, Z. 2020. Armored mites, beetle mites, or moss mites: the fantastic world of oribatida. Front. Young Minds 8:545263. doi: 10.3389/frym.2020.545263

5. Barreto, C., and Lindo, Z. 2020. Decomposition in peatlands: who are the players and what affects them? Front. Young Minds 8:107. doi: 10.3389/frym.2020.00107

6. de Souza Machado, A. A., Horton, A., Davis, T., and Maaß, S. 2020. Microplastics and their effects on soil function as a life-supporting system. In: The Handbook of Environmental Chemistry, eds D. He and Y. Luo. Cham: Springer. p. 1-24.

7. Rodriguez-Seijo, A., Lourenço, J., Rocha-Santos, T. A. P., da Costa, J., Duarte, A. C., Vala, H., et al. 2017. Histopathological and molecular effects of microplastics in Eisenia andrei Bouché. Environ. Pollut. 220:495-503. doi: 10.1016/j.envpol.2016.09.092

8. Zhu, D., Qing-Lin, C., Ana, X., Yanga, X., Christiec, P., Ked, X., et al. 2018. Exposure of soil collembolans to microplastics perturbs their gut microbiota 
and alters their isotopic composition. Soil Biol. Biochem.

116:302-10. doi: 10.1016/j.soilbio.2017.10.027

9. Huerta Lwanga, E., Mendoza Vega, J., Quej, V.K., de los Angeles Chi, J., Sanchez del Cid, L., Chi, C., et al. 2017. Field evidence for transfer of plastic debris along a terrestrial food chain. Sci. Rep. 7:14071. doi: 10.1038/s41598-017-14588-2

10. Huerta Lwanga, E., Thapa, B., Yang, X., Gertsen, H., Salánki, T., Geissen, V., et al. 2018. Decay of low-density polyethylene by bacteria extracted from earthworm's guts: a potential for soil restoration. Sci. Total Environ. 624:753-7. doi: 10.1016/j.scitotenv.2017.12.144

SUBMITTED: 02 November 2020; ACCEPTED: 22 July 2021; PUBLISHED ONLINE: 18 August 2021.

EDITED BY: Rémy Beugnon, German Centre for Integrative Biodiversity Research (iDiv), Germany

CITATION: Barreto C, Rillig MC, Waldman WR and Maaß S (2021) How Soil Invertebrates Deal With Microplastic Contamination. Front. Young Minds 9:625228. doi: $10.3389 /$ frym.2021.625228

CONFLICT OF INTEREST: The authors declare that the research was conducted in the absence of any commercial or financial relationships that could be construed as a potential conflict of interest.

COPYRIGHT @ 2021 Barreto, Rillig, Waldman and Maaß. This is an open-access article distributed under the terms of the Creative Commons Attribution License (CC BY). The use, distribution or reproduction in other forums is permitted, provided the original author(s) and the copyright owner(s) are credited and that the original publication in this journal is cited, in accordance with accepted academic practice. No use, distribution or reproduction is permitted which does not comply with these terms.

\section{YOUNG REVIEWERS}

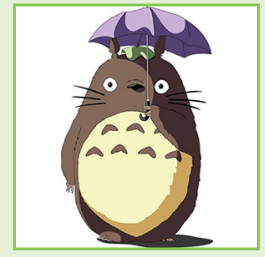

\section{ASTÈRE, AGE: 8}

My age is 8 . I like reading, doing DIY, drawing, coloring, art, maths, writing, and history. My favorite books are Harry Potter and Percy Jackson.

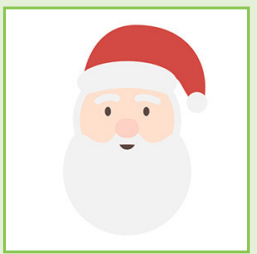

\section{JUNIE, AGE: 10}

I have many hobbies but the ones that I do the most are cooking, reading, drawing, and sewing. I go to a primary school in a big city in the UK and my age is 10 . My favorite books are Percy Jackson, books by Judy Blume, Scarlet and Ivy, and North child. 

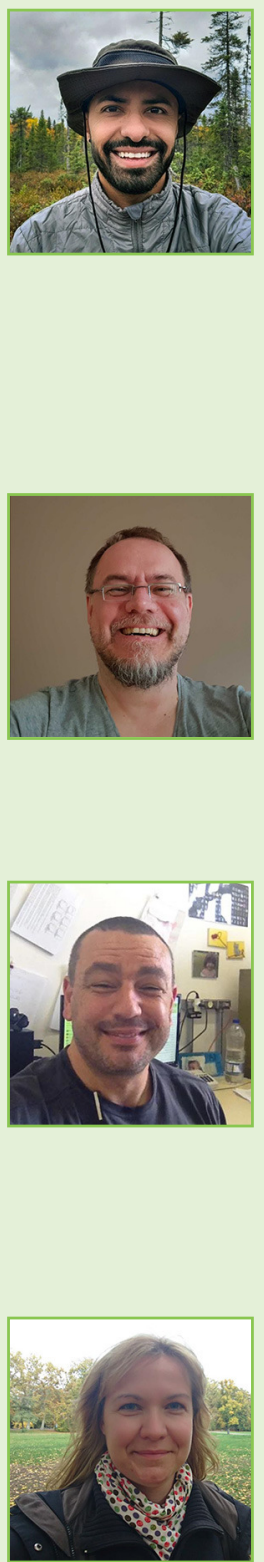

\section{AUTHORS}

\section{CARLOS BARRETO}

At a very young age, Carlos realized that he liked animals, maybe too much. In school, science was always his favorite discipline, all the way through to high school. That is when he decided that he wanted to do something that involved science and animals. He tried to be a vet; it did not work out. No regrets. So, he became an ecologist a few years later, and since then, he has been working with little animals (mostly insects and mites) in tropical forests, iron ore and limestone caves, boreal forests, urban fields, and peatlands on three continents: South America, North America, and Europe. * ${ }^{*}$ barreto@uwo.ca; ${ }^{\dagger}$ orcid.org/0000-0003-2859-021X

\section{MATTHIAS C. RILLIG}

Matthias likes soil and all the critters in it, not just the animals. Actually, his favorite are the fungi. His favorite soil process is soil aggregation, the formation of the little crumbs of soil. Matthias is a professor at Freie Universität Berlin and gets to think about soil and what is going on in there all day. Currently he is very interested in how soils are being affected by a wide range of factors, including microplastics. torcid.org/0000-0003-3541-7853

\section{WALTER R. WALDMAN}

Walter is a proud Brazilian chemist who loves music, chemistry, food, cinema, and polymers. His first experiment involved chewing gum and the hair of an ex-friend. The experiment did not end well for all the participants, but the adhesive power of polyisoprene was confirmed, and a polymer scientist was born that day. Now he tries to understand the role of polymer degradation on the impact of microplastics. When he has some free time, you can find him reading something about chemistry and polymers. And eating... ${ }^{\dagger}$ orcid.org/0000-0002-7280-2243

\section{STEFANIE MAA}

Stefanie wanted to become a make-up artist or costume designer but due to lack of art skills, she moved on to something completely different: biology. When she was introduced to tropical insects and mites of tree bark during her studies, she became fascinated by their beauty and diversity. She then worked on soil insects and mites and has become a passionate and curious soil ecologist who wants to understand the feeding relationships, reactions to pollutants (like microplastics), and distribution patterns of her beloved soil creatures. ${ }^{\dagger}$ orcid.org/0000-0003-4154-1383 